\title{
Imperial policy of the Russian Federation versus cohesion and coherence of NATO's new strategic concept
}

\section{Danuta Mierzwa ${ }^{1}$ (D) Marek Tomaszycki ${ }^{1}$ D}

Accepted: 5 July 2021 / Published online: 30 September 2021

(C) The Author(s) 2021

\begin{abstract}
The article presents a multifaceted analysis of threats to Central and Eastern Europe by the Russian Federation. Russia's imperial policy, as set out in Gerasimov doctrines in 2013 and 2019, forced NATO to develop a new strategic concept. NATO's new strategic concept was put forward at NATO Summits of 2018 and 2019 by Member State leaders, and it defines a new strategy to deter a potential aggressor. The new strategic concept is based on NATO's strategy of cohesion and coherence discussed in detail in this article. NATO's new strategic concept was a result of Russian military operations in Ukraine, Georgia, Estonia and Montenegro, as well as the deployment of Russian forces on Russia's western and southern borders. Nowadays, when the application of a new strategy can give a significant advantage, Russia's imperial policy using cutting edge technology seems unpredictable, as it does not give the enemy a chance to repel an attack in a timely manner. Thus, NATO's new strategic concept contributes to creating a space of security cooperation for Member States.
\end{abstract}

Keywords NATO $\cdot$ Strategic concept $\cdot$ Russian Federation $\cdot$ Threats $\cdot$ Imperial policy

\section{Introduction}

The Alliance of NATO, since its inception, has been based on four main pillars: ideological, political, economic and military. Ideologically, the Member States share fundamental principles such as individual freedom, democracy, the rule of law and sovereignty of the state. Politically, there is a necessity for consensus among the

Danuta Mierzwa

danuta.mierzwa@awl.edu.pl

Marek Tomaszycki

marek.tomaszycki@awl.edu.pl

1 Faculty of Management, General Tadeusz Kościuszko Military University of Land Forces,

Wrocław, Poland 
member states on common interests, objectives and commitments. From the economic viewpoint, the Allies pledge to incur the designated military expenditures and other security-related expenditures - they commit to cost-sharing. With regard to the military organization, NATO is based on the principle of strong, integrated, organized, well-trained, effective and mobile troops.

NATO achieves its objectives by upscaling its readiness, response and military capabilities to deter an adversary. It aims at maintaining military forces in the right place and time capable of deterring or, if necessary, repelling an adversary. In this context, NATO leaders, who are aware of the fact that unity is essential for success, comply with the principles of "cohesion" and "coherence". Hence, "cohesion" and "coherence" have become distinctive indicators of NATO's current strategic concept. According to the former NATO Secretary General Anders Fogh Rasmussen, "the Alliance that cannot ensure collective defence loses cohesion in achieving collective security". In order to clarify the principles that are crucial for the implementation of the new strategy, it is necessary to understand what "NATO's cohesion" and "NATO's coherence" mean. ${ }^{1}$

NATO's cohesion means a level of political and ideological unity as well as solidarity between the members of the Pact. It mainly refers to the principles on which the Alliance is based. This is particularly true of the Member States' commitment to collective defence, threats and challenges facing the Alliance.

NATO's coherence refers to consensus among the Member States in order to guarantee the Alliance's capabilities and capacities necessary to ensure the effective implementation of NATO's missions. It involves strategic plans, resource requirements, material capabilities, operational procedures, command structures, the number of soldiers and logistical infrastructure (Hodges et al. 2019).

The dynamics of events after 2014 as well as the emergence of new international threats (e.g. ISIS, refugees, epidemics) has led to increasing expenditures on security and collective defence (Grygiel and Wess Mitchell 2014). This issue seems to be extremely important and therefore still remains within the realm of discussions among the politicians and bodies responsible for the state security. With time and transformations in geopolitical and military situations in the world, the requirements for the North Atlantic Pact have also changed, which has inspired the authors to write this article.

\section{The aim of the article is to assess the strategic objectives of the North Atlantic Alliance in the context of multi-faceted threats created by the Russian Federation}

The article is based on the following methods: monographic, analysis, expert, participatory observation, induction and deduction, synthesis and comparisons. The article is based on the following sources: available literature, magazines, press articles,

\footnotetext{
1 Speech by NATO Secretary General Anders Fogh Rasmussen, nato.int, 12 March 2010. https://www. nato.int/cps/en/natolive/opinions_62143.htm. Accessed 10 Nov 2019.
} 
interviews, reports, authors' own experiences and documents found on the websites of NATO and the Russian Federation, mostly in English or Russian.

\section{Imperial policy of the Russian Federation and threats to Central and Eastern Europe}

\section{Historical conditions of expansionism and Russian domination in Europe}

The fall of the Berlin Wall, one of the symbols of the Cold War, followed by the collapse of the Warsaw Pact in political and military terms as well as the USSR disintegration, paved the way for a new era in the history of Europe and the world. It also created a challenge for NATO that until then treated the Warsaw Pact, and in particular the USSR, as its main enemy.

The new geopolitical situation gave rise to major changes in the structure of the North Atlantic Pact and it called for a new approach towards countries outside the "Iron Curtain". As part of the plan to increase security in Europe, NATO launched programmes enabling the former EU states, as well as countries that just gained independence as a result of the disintegration of USSR and the Socialist Federal Republic of Yugoslavia, to join the Pact structures. Consequently, the number of NATO member states increased from 16 in 1991 to 29 in 2017. (Probably, North Macedonia will officially become the 30th member of NATO in 2020. In February 2019, NATO ambassadors signed a protocol for the accession of North Macedonia into the Alliance.)

Simultaneously, NATO's strategic concept changed fundamentally. In 1991, the so-called new strategic concept came into existence aiming at maintaining sufficient conventional and nuclear forces capable of deterring potential aggressors and ensuring the measures to prevent armed conflicts in the world. Primarily, the new strategic concept focused on ensuring the security of the allied states with regard to diverse and multi-directional international threats (ethnic and territorial conflicts, proliferation of mass destruction weapons and armament technologies, interruption of the supply of strategic raw materials, terrorism and sabotage).

In 1999, following the experience of NATO's mission in the former Yugoslavia, the strategy was updated by introducing the concept of "non-Article Five operations", which mainly consisted in crisis management operations, i.e. operations by use of armed forces aimed at withstanding crisis situations, which might threaten regional or global security and lead to human rights violations (Banasik 2009).

Apparently, all the strategic concepts after 1991 failed to identify a potential enemy. Russia was no longer perceived as a NATO's enemy either. Despite the warnings of the former Eastern Block's states regarding the mentality of Russian leaders and their historical inclinations towards expansionism and dominance in Europe and Asia, Russia was still treated as an ally or a friend.

In particular, the "liberal" approach of the "old NATO member states" towards Russia began after Vladimir Putin took office as Prime Minister and then became president (26 March 2000). Some even began to speak of a "new NATO" including Russia. That tendency was reflected by the world's ranking of politicians: December 
2007 "Man of the Year" according to the Times magazine, August 2008 "The Most Influential Man in the World" Vanity Fair, November 2009 "The Third Most Influential Man in the World" Forbes, December 2012 "The Second Most Powerful Man in the World" Foreign Policy, October 2013 "The Most Influential Man in the World" Forbes, December 2013 "Man of the Year" by the Times. ${ }^{2}$ His speeches on Omnipotent Russia and Peter the Great, of whom he is an admirer and who he tries to imitate, remained "unnoticed". The first significant, but not for all, symptom of Putin's and Russia's aggressive policy became evident by the Georgian conflict in 2008. However, it was quickly treated as an "event" and despite the efforts of Poland and the Baltic states, it did not provoke any major changes in the NATO policy. It was Russia's aggression in Ukraine in 2014, the annexation of Crimea and the subsequent conflict in Donbass that radically changed NATO's approach and resulted in a "new" understanding of the threat posed by Russia. In addition, the two socalled "Gerasimov doctrines" announced in 2013 and 2019, as well as their implementation, no longer allowed any other interpretation of Russia's strategy as merely aggressive and revisionist.

The situation after 1991, where the concepts did not identify a specific adversary, led to a decrease in defence expenditures in many countries, a decrease in the personnel of armed forces, the reduced presence of US troops in Europe as well as a significant decrease in the amount of logistical stocks, military equipment and infrastructure (Mierzwa et al. 2020).

It was not until the events of 2014 that a new perspective was adopted and dynamic changes started to occur both in NATO and the EU (Banasik and Panek 2017).

The NATO Summit of 2014 in Newport and the following ones in Warsaw of 2016, in Brussels of 2017 and 2018, completely changed the approach to real threats (Adamsky 2015a, b). The recent NATO Summit of December 2019 in London has been particularly important for Poland and the Baltic states. ${ }^{3}$

Since 2014, Russia has been identified as the major security threat and the new defence plans have aimed at strengthening "the NATO eastern wall" (Koziej and Pietrzak 2014).

\section{Russia's military intervention in Central Europe}

Undoubtedly, there are many different threats to Central and Eastern Europe but no one doubts that it is Russia with President Vladimir Putin that raise the greatest

\footnotetext{
${ }^{2}$ Wtadimir Putin, wikiwand.com. https://www.wikiwand.com/pl/W\%C5\%82adimir_Putin. Accessed 25 Nov 2019.

3 NATO Summit in London. Jens Stoltenberg concludes the proceedings. The "London Declaration" was adopted". https://wiadomosci.wp.pl/szczyt-nato-w-londynie-jens-stoltenberg-podsumowuje-obrady-przyj eto-deklaracje-londynska-6453106443692161a. Accessed 15 Dec 2019.
} 
concerns. Analysing the inflammation points in Central and Eastern Europe or its vicinity, Russia's direct or indirect involvement can be noticed everywhere. ${ }^{4}$

Since the early 90 s of the last century, the USSR and later Russia have contributed to the emergence of a number of separatist republics. On September 2, 1990, in the area of Moldova, the separatist Transnistrian Republic of Moldova declared its willingness to remain part of the USSR, and others did that as well: in 1991 in the area of Georgia - the Republic of South Ossetia, in 1992 the Republic of Abkhazia, in 2014 in the area of Ukraine-the People's Republic of Donetsk and Luhansk confirmed annexation of Crimea into Russia (Belkin 2014a, b). Russia's aggressive and overtly military interventions occurred during the war with Georgia in 2008 and Ukraine in 2014 as well as the incident in The Kerch Strait of November 2018. Russia's more sophisticated, covert actions include a cyber attack on Estonia in April 2007 (Wierzbicki 2015a, b), the coup trial in Montenegro in $2016,{ }^{5}$ the attempt to block the Macedonian agreement with the Greeks in $2019,{ }^{6}$ or the conduct of reconnaissance exercises and operations in Norway by the Russian Specnaz in $2019 .^{7}$ These are just examples of Russia's actions within the framework of a "hybrid war" or "conflict below the threshold of war" (Banasik 2016; Allen et al. 2017a, b, c).

\section{Principles of warfare according to General Gerasimov's doctrines}

It is the so-called "hybrid war" and "conflict below the threshold of war" that underlie "Gerasimov Doctrine" put forward in 2013 at the Academy of Military Sciences. In his opinion, the "principles of war" changed. As a result, non-military combat operations became the most important military measures (Boston et al. 2018a, b). ${ }^{8}$

According to the doctrine, it is increasingly important to use a variety of political, economic and humanitarian instruments combined with the mood manipulation of civilians living in the area of conflict. These combat actions need to be supported by military measures, in particular information warfare and special operations. The evident use of armed forces-most often in the form of peace keeping and humanitarian

\footnotetext{
4 "America is in the game and America will win". Four pillars of security according to Trump, the portal of Tvn24, 18 Dec 2018; https://www.tvn24.pl/wiadomosci-ze-swiata,2/usa-trump-oglosil-nowa-strategiebezpieczenstwa-narodowego,799709.html. Accessed 18 Feb 2018.

5 They wanted to overthrow the government and kill the Prime Minister. Before that, they used to spy in Poland. https://www.tvp.info/40367524/rosja-jak-gru-chcial-przeprowadzic-pucz-w-czarnogorze. Accessed 03 Jan 2020.

6 Greek-Russian tensions with Macedonia in the background, https://www.osw.waw.pl/pl/publikacje/ analizy/2018-07-25/napiecia-grecko-rosyjskie-Z-macedonia-w-tle. Accessed 03 Jan 2020.

7 Specnaz carried out a reconnaissance in Norway. Russia denies it, https://www.rp.pl/Wojsko/19093 9940-Specnaz-przeprowadzil-rekonesans-w-Norwegii-Rosja-zaprzecza.html. Accessed 03 Jan 2020.

8 Decree of President of the Russian Federation on the National Security Strategy of the Russian Federation, Moscow, 2015. https://poland.mid.ru/web/polska_pl/koncepcjapolitykizagranicznejfederacjirosyjsk iej//asset_publisher/x9WG6FhjehkG/content/strate-gia-bezpieczenstwa-narodowegofederacjirosyjskiej? inheritRedirect $=$ false \&redirect $=$ https $\% 3 \mathrm{~A} \% 2 \mathrm{~F} \% 2 \mathrm{Fpoland}$.mid.ru\%3A443\%2Fweb\%2Fpolska_pl\%2Fkon cepcja-polityki-zagranicznej-federacji-rosyjskiej\%3Fp_p_id\%3D101_INSTANCE_x9WG6FhjehkG\% 26p_p_lifecycle\%3D0\%26p_p_state\%3Dnormal\%26p_p_mode\%3Dvie-w\%26p_p_col_id\%3Dcolumn2\%26p_p_col_count\%3D1. Accessed 18.
} 
missions - is only allowed at a later stage of a conflict in order to reach the ultimate success (Gorenburg 2017). ${ }^{9}$

According to Gerasimov, the development of information technologies significantly improved the communication process between the operating armed forces and their commands. The modern information space might also be used to decrease the enemy's military capabilities. As an example, Gerasimov presented North African countries, where online social networks were used to mobilize local people and influence authorities (Allen et al. 2017a, b, c; Bartles 2016).

The Gerasimov doctrine places a great emphasis on asymmetric activities, in particular the use of special units and internal political opposition for the purpose of spreading the conflict in the entire hostile area. Mobile mixed combat troops, which do not engage in front battles against the enemy, have a special role to play. Gerasimov believes that such a strategy blurs the differences between strategic, operational and tactical operations, as well as between offensive and defensive operations" (Banasiak 2019). ${ }^{10}$

In March 2019, precisely at the same place of the Academy of Military Sciences, as part of the lecture, Chief of the General Staff of Russia presented the new war doctrine of the Russian Federation. That lecture constituted the development and modernization of the directions and tasks outlined by Gerasimov in the first "doctrine". 11

General Gerasimov outlined the programme of preparations for large-scale hostilities aimed at neutralizing retaliatory actions. He called it an "active defence strategy" and a "complex of pre-emptive operations" aimed at neutralizing threats to the Russian state, taking over and maintaining a strategic initiative. To achieve that, it was essential to create and improve nuclear and non-nuclear deterrents, so that any form of impact on Russia or its allies might be met with a radical response. For that purpose, the army was provided with modern equipment, including completely new types of weapons. One of the innovations of the strategy was the creation and development, based on modern information and telecommunication technologies, of a single system coordinating the integrated forces and measures of reconnaissance, destruction and command as well as control of troops and weapons systems. That could be arranged in order to detect and determine targets as well as carry out selective attacks on critical objects within a time scale close to real, using strategic and operational-tactical as well as non-nuclear weapons.

Another innovation mainly aimed at improving the large-scale use of military robots and unmanned aircraft in order to increase efficiency of solving a wide range of tasks. Moreover, its main target was creation of a system capable of countering unmanned aerial vehicles and precision weapons. The forces and measures of

\footnotetext{
${ }_{9}$ War doctrine of the Russian Federation, National Security Bureau. https://www.bbn.gov.pl/ftp/dok/03/ 35_KBN_DOKTRYNA_ROSJI.pdf. Accessed 18 Feb 2018.

${ }^{10}$ Hybrid war-the future challenge? Selected issues. https://www.abw.gov.pl/pl/pbw/publikacje/przeg lad-bezpieczenstwa-4/1213,Przeglad-Bezpieczenstwa-Wewnetrznego-WYDANIE-SPECJALNE.html. Accessed 05 Jan 2020.

${ }^{11}$ New "Gerasimov Doctrine". https://eurokurier24.pl/index.php/bezpieczenstwo/item/206-nowa-doktr yna-gierasimowa. Accessed 05 Jan 2020.
} 
electronic warfare, which allow selective action in terms of the type of object, its structure and temporal criticality, had to play a decisive role (Фененко 2016).

In particular, the reality of new military measures transferred warfare to the information space. Thus, the information technology became one of the most dangerous types of weapons. The information space, with no clearly defined state borders, provided the opportunity of remote, hidden impacts not only on the critical information infrastructure, but also on the state's civilians, directly affecting the sense of security. The conception was designed to ensure the sustainable development and expansion of the Armed Forces of the Russian Federation and to equip them with modern weapons in due time.

The atomic triad still plays and is going to play a key role in maintaining strategic parity. The Russian strategic arsenal, like the American one, is not accidentally referred to as the "atomic triad". It consists of three components and that division was based on the type of transmission of nuclear warheads. The division accounts for three areas: marine, air and land. The marine area includes nuclear submarines armed with intercontinental ballistic missiles (SLBM). Airspace comprises strategic aviation, long-range bombers carrying nuclear weapons. Land, which is the largest area, comprises intercontinental ballistic missiles (ICBMs) that can be fired from the mainland by means of mobile or solid launchers (silos). Such an atomic triad allows a simultaneous nuclear attack from land, air and sea. In fact, the triad also prevents the enemy from destroying Russia's entire nuclear forces with the first strike, giving it the opportunity of an immediate nuclear response. In October 2019, the largest ever nuclear triad exercises were conducted in Russia under the codename "Grom 2019". The official objective of the manoeuvres was to practice military actions in the event of escalation of the conflict around the borders of the Russian Federation. Notably, it was not just about simulating a retaliatory strike-Russia enacted the scenario of a nuclear weapons impact in which it was the first to attack. ${ }^{12}$

Figure 1 presents the deployment of Russia's "Atomic Triad" forces and measures at the end of 2019. It is noteworthy that two of three Missile Armies, about $50 \%$ of air forces and about $66 \%$ of marine forces of the Triad are located in the Western and Southern Military Districts.

The share of modern weapons in the nuclear component amounts to $82 \%$ and will continue to increase. Research will intensely search for the new ways of use of modern weapons in order to counter possible military attacks of a potential enemy both in space and from space.

Given the complexity of modern weapons and hard conditions of their production in due time after the outbreak of hostilities, the required quantities of weapons need to be produced in advance to supplement the equipment in peacetime. In his speech, Gerasimov also emphasized Russia's aspirations to gain "technical, technological and organisational advantage over potential adversaries" and to be "one step ahead of the adversary" that was identified as NATO and the USA.

\footnotetext{
12 The last 10 min of life on Earth. How Russia practiced nuclear warfare, https://www.tvp.info/45248 250/ostatnie-10-minut-zycia-na-ziemi-jak-rosja-cwiczyla-wojne-jadrowa/. Accessed 03 Jan 2020.
} 


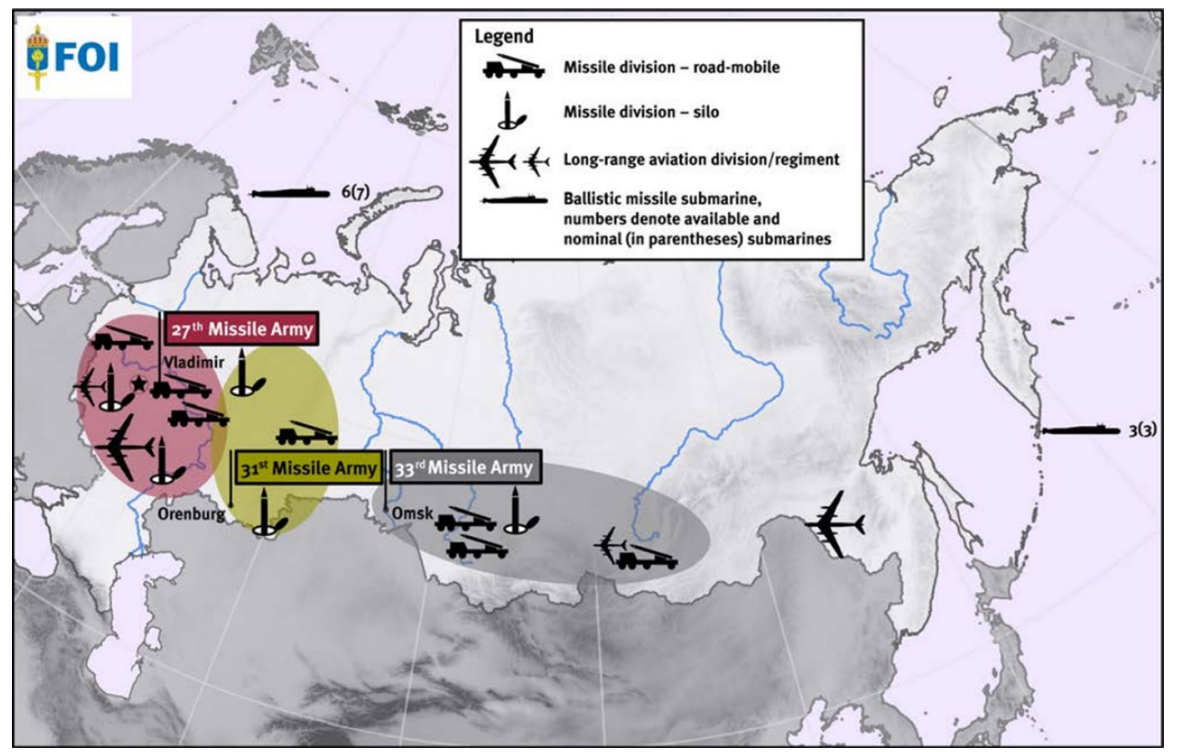

Fig. 1 Deployment of the "Nuclear Triad" units in Russia in 2019. Source: ROB-RUFS Order of Battle data base, FOI, September 2019

\section{Implementation of Russia's strategic objectives}

It is noteworthy that the first Gerasimov doctrine in 2013 was implemented already a year later in Ukraine. Does the presentation of the supplement to the doctrine in 2019 mean that it should be expected to be implemented any time soon?

No one knows that, but hopefully not. However, it is worth noting what efforts Russia has undertaken to strengthen its forces and military capabilities in Europe over the last decade. By the end of 2019, three army commands, five new division commands and 15 new mechanized regiments (motorized, mechanized and airborne troops) were deployed in the Western Military District. The 76th Airborne Division, which is the first Russian division of this kind, is located $28 \mathrm{~km}$ from the Estonian border and consists of three assault regiments fully provided with equipment and personnel.

The deployment of the aforementioned commands, units, forces and measures distributed in Russia's Western Military District at the end of 2019 is presented in Fig. 2. It illustrates the forces and measures distributed in the Kaliningrad Oblast and at the Baltic Sea. Assessing the potential impact of those military capabilities, also from the regions of Belarus and Transnistria, it is evident that the forces might pose a real threat as they are capable of conducting effective surprise actions towards NATO Eastern Wall states, including Finland and Sweden.

Compared to NATO forces in the Baltic states, the axis is clearly tilted in Russia's favour. Even without taking into account the military capabilities of the Kaliningrad Oblast, Russia has an absolute advantage in terms of offensive equipment—tanks, fighter aircrafts and missile artillery. The Russian armed forces are 


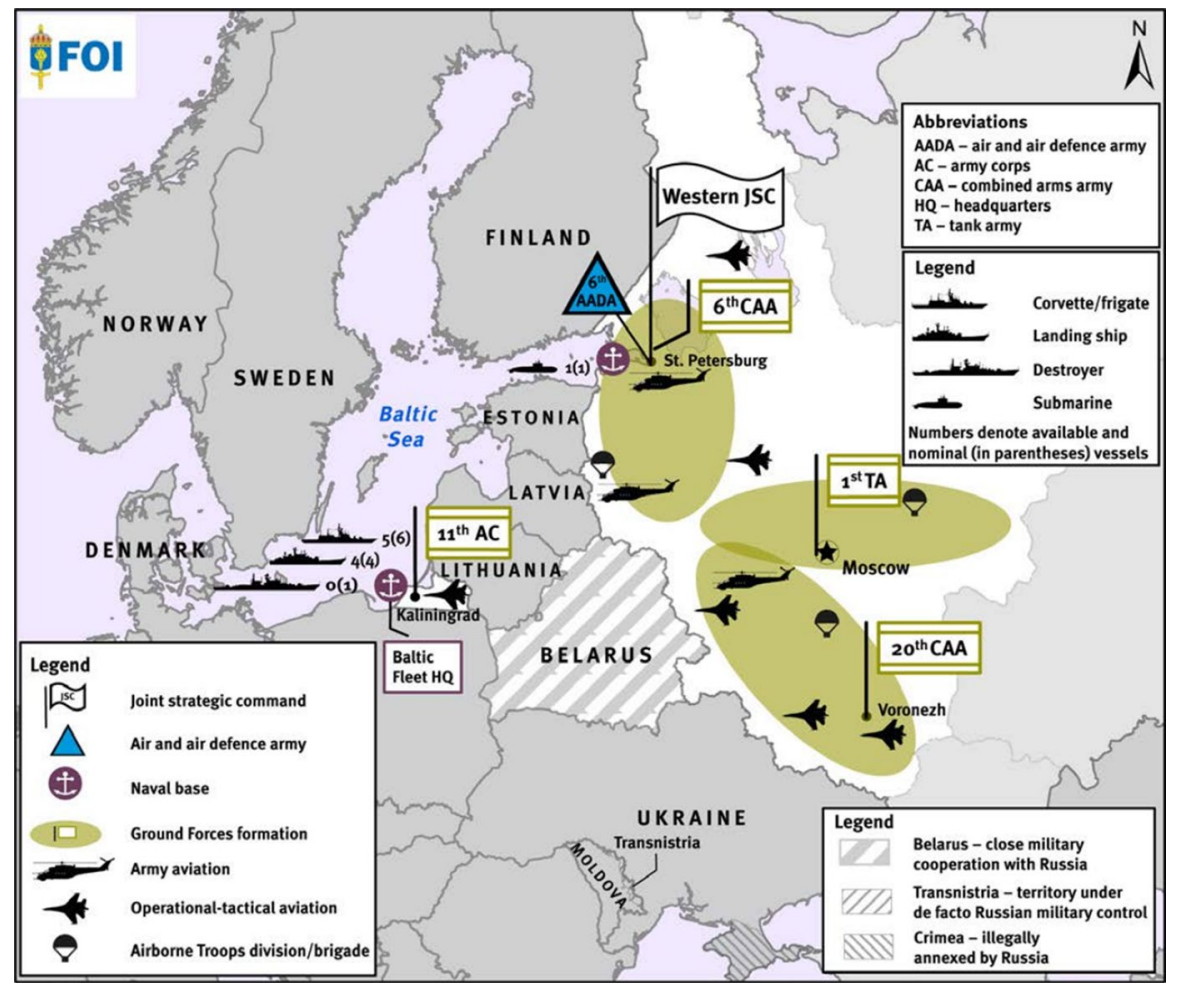

Fig. 2 Deployment of the selected units in Russia's Western Military District in 2019. Source: ROBRUFS Order of Battle data base, FOI, September 2019

also equipped with Iskander ballistic missiles permanently deployed $120 \mathrm{~km}$ from the Estonian border and $45 \mathrm{~km}$ from the Lithuanian border.

This military potential threatens the Baltic states from two sides-the Kaliningrad Oblast and the Leningrad Oblast.

Notably, NATO is not equipped with a system comparable to Iskander in Europe.

Figure 3 presents the deployment of Russia's armed forces in the Southern Military District and Crimea as well as of the Russian Navy vessels in the Black Sea. The main task of the Southern Military District forces is to protect and defend Russia's south-western border. However, the forces pose an evident threat to Turkey, Bulgaria, Romania, Georgia and Ukraine, which constitute the NATO south-eastern border. The forces and measures deployed in that area are also capable of attacking Poland and the Baltic states and may substantially strengthen the military operations of Russian troops in "our area".

Russian Armed Forces' exercises conducted in 2019 revealed an increasing accuracy and complexity of their systems. One example could be the exercise conducted by the Navy forces "Ocean Shield 2019" in which groups of ships practically carried out hostilities in the Danish Strait and the Atlantic (previously 


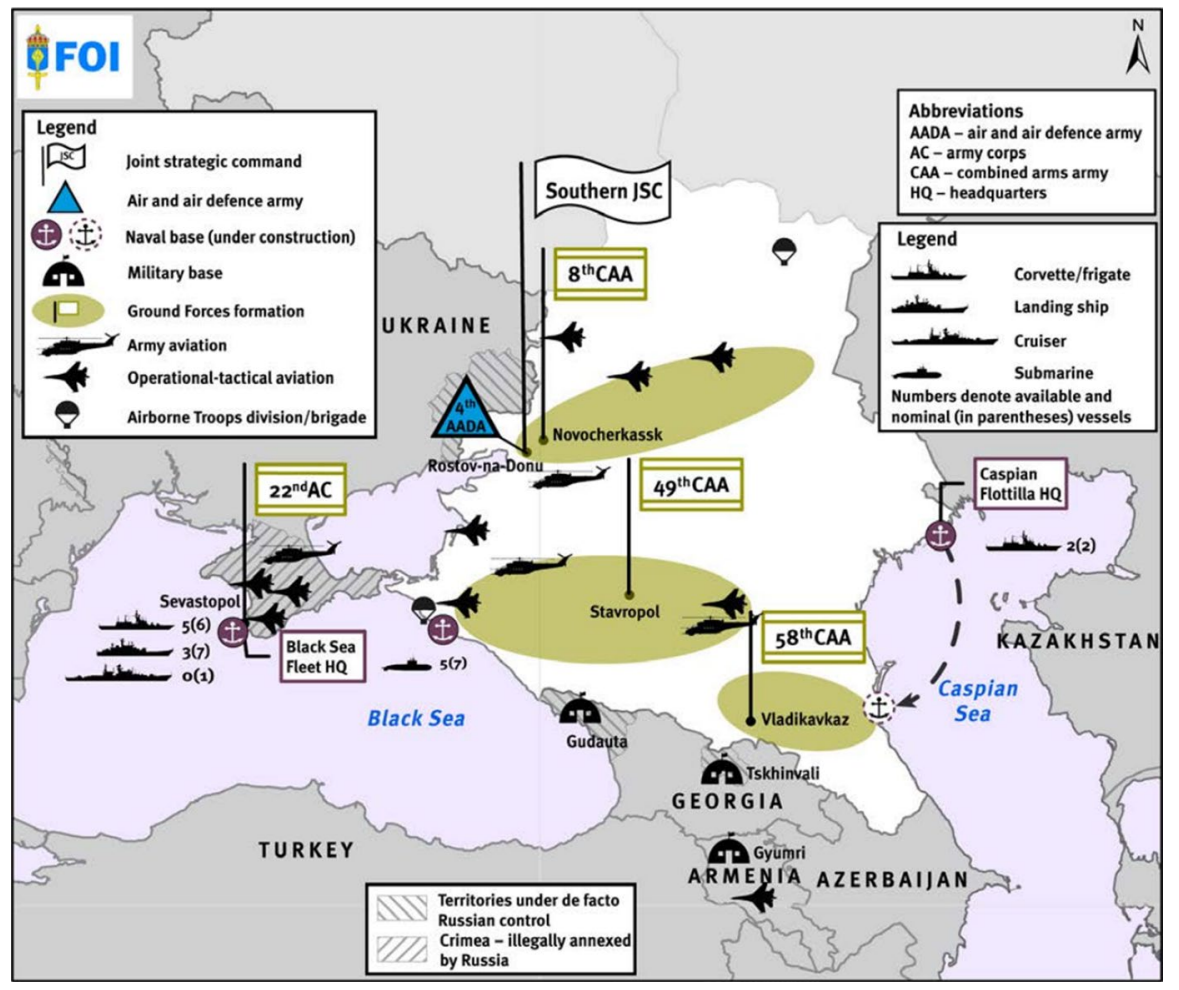

Fig. 3 Deployment of the selected units in the Russian Southern Military District in 2019. Source: ROBRUFS Order of Battle data base, FOI, September 2019

those were only exercises in the form of war games) (Estonian Foreign Intelligence Service 2020).

The biggest manifestation of strength, over the last five years, has been the exercise "Zapad-2017". Nearly 100,000 troops took part in the exercises in the Baltic region and the main task involved conducting combat actions against the "Western Forces". As part of the exercises, Russian troops practiced a nuclear attack on Poland and Sweden. During the exercises, Russian forces posed a real threat to Finnish research vessels in the Baltic Sea, and often violated the space of neighbouring countries (they actually tested NATO system forces and on-duty measures). The exercises involved practicing the transfer of forces and measures by various means of transport (mainly by rail) from all military districts to Russia's western border.

In April 2018, Russia conducted three-day exercises in Baltic waters near Lithuania in close proximity to NATO waters. During the exercises, combat munitions were put into action so close to NATO's border for the first time. The consequence of those actions was, among others, forcing Sweden to partially close the civilian flight zone over the firing space of Russian warships (Hodges et al. 2019).

The direct comparison between the military capabilities of Russia and NATO indicates that there is no real threat in terms of quantitative or qualitative advantage 
in Russia's favour. On the contrary, NATO is in the lead, with a huge advantage of both equipment and personnel as well as technology, quality and quantity. However, there are areas in favour of Russia. These include WRE (radio-electronic warfare), aviation and air defence capabilities, radar systems as well as nuclear carriers and weapons. Needless to mention other types of mass destruction weapons which, according to the International Humanitarian Law of Armed Conflict (IHL), ought to cease to exist, whereas Russia is highly likely to possess them (chemical weapons were used in counter-terrorism operations and special combat operations).

Over the past two decades, the Russian defence industry has developed, researched and introduced dozens of radio-electronic warfare systems capable of disrupting and completely immobilizing most of the forces in the areas of land, air and water. Russian technologies are effective at fighting aircrafts, cruise missiles, radars, conventional missiles and unmanned aircrafts. The latest implemented system is the Palantin system, which has been deployed in the Kaliningrad Oblast and Crimea. This system is able to disrupt the operation of AWACS at a distance of $250 \mathrm{~km}$. Probably, it is also able to disrupt all radio, GPS and mobile systems as well as create the so-called apparent targets that mask the correct flight paths of projectiles fired from the Iskander launcher. Thus, combating and destroying Iskander missiles have become even more difficult. Moreover, the system also functions as a reconnaissance platform (Cranny-Evans 2019; Hodges et al. 2019).

The deployment of Iskander and Krasucha (Gawęda 2015), as well as Palantin and aeronautical defence systems in the Kaliningrad Oblast and Crimea, including the S-300 and S-400, create strong Anti-Access/Area Denial (A2/AD) nodes with the simultaneous capability to strike by means of airborne and land forces within the depth of their practical impact range (A2/AD nodes).

Another threat worth noting, particularly important for NATO Eastern Wall states, is Russia's conduct of operations which cannot be immediately repelled by the Alliance due to their little scale. They take place in the form of quick, limited or offensive operations giving Russia the advantage of "facts made" and allowing it to join into the peace talks from that position.

Figure 4 presents the summary of the estimated military capabilities, presented earlier in individual innovation trends, of the Russian Federation's Armed Forces in Europe at the end of 2019. It illustrates the deployment of the Strategic Connected Commands, the army and corpses as well as "inaccessible areas" and potential targets to be attacked in the event of a conflict (air bases, airports and radar systems). It is worth noting that almost the entire area of Poland is an anti-access zone (A2/AD) (Gawęda 2018), which means that any allied defence support from the air, at least in the first phase of a conflict, will be very difficult. Operations of the Polish aviation and capability to command them also seem highly problematic. Unfortunately, that confirms the likelihood of limited offensive capabilities as described above.

Russia's significant asset is also the fact that it constitutes a single entity in contrast to NATO whose forces, which guarantee the security of Central and Eastern European states, are distributed throughout the world (including the US and Canada). Thus, the distance gives Russia a big advantage. The USA, being the major pillar of NATO, have several sensitive security spots and, therefore, have to operate on many levels, not just watching over their own national and NATO's interests, 


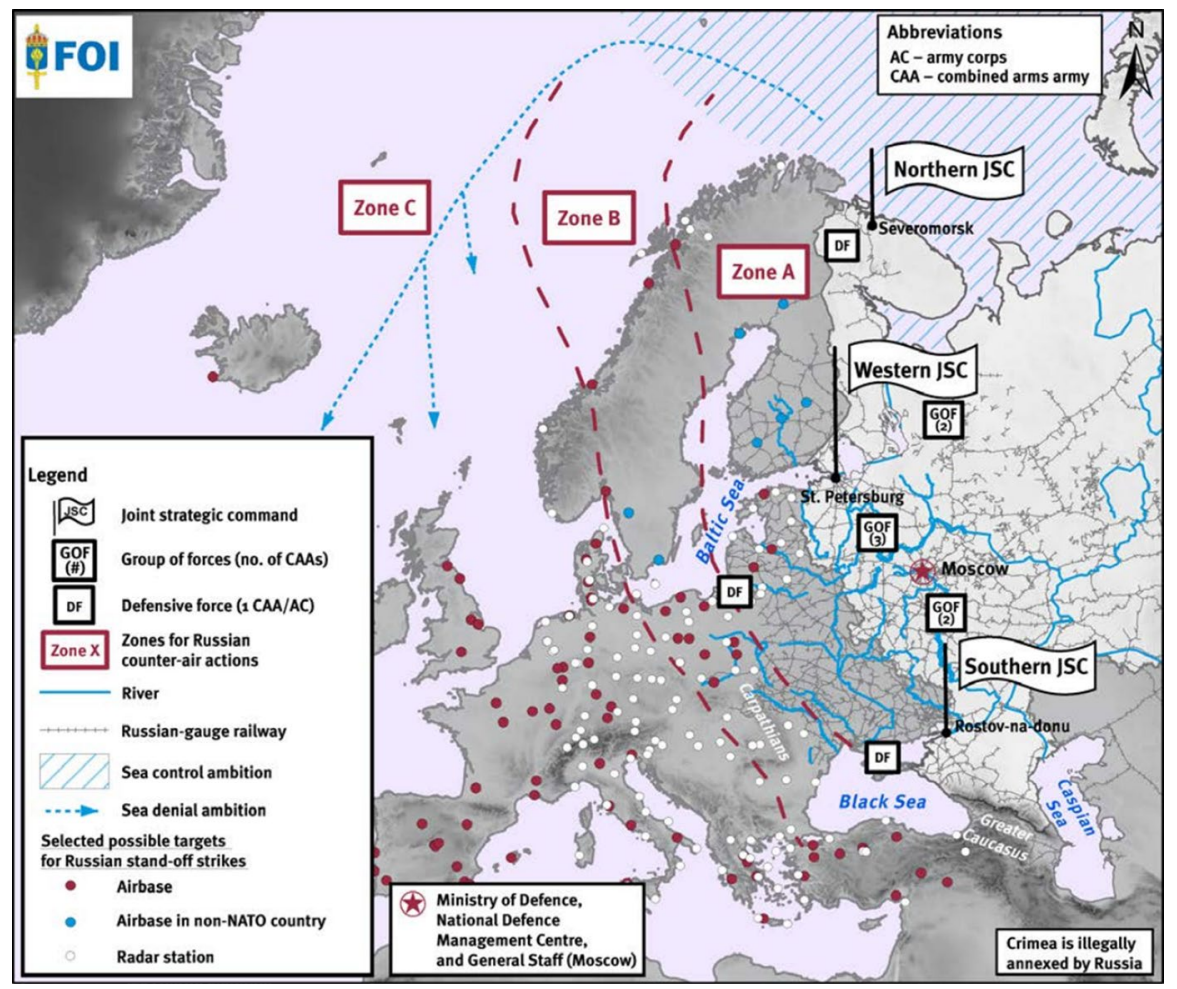

Fig. 4 Estimated military capabilities of the Russian Armed Forces in Europe. Source: ROB-RUFS Order of Battle data base, FOI, September 2019

but also, in particular, European states neighbouring with Russia. Moreover, the distance and response time create problems, while Russia has the freedom to choose the time and space to provoke and attack.

However, it is not the military threat that is the most dangerous for NATO. The main threat are the attempts made by Russia to bring individual member states into conflict with each other in order to break down NATO's cohesion. Success of such attempts could create a space for Russia to undertake possible military actions.

The tools provided by the supplemented Gerasimov doctrine entitle Russia to use all methods and measures of combat such as: pre-emptive attacks, impacts on civilians and administration centres (psychological and information operations), as well as the use of nuclear weapons. In other terms, it entitles Russia to wage a total war at a convenient time and place. 


\section{The directions of the Alliance's strategic adaptation to the revised security situation undertaken at NATO Summits in recent years}

The main innovation directions to be followed by the North Atlantic Alliance, were set out at the summits of NATO leaders. The talks focused on the Newport Summit of 2014 and the Warsaw Summit of July 2016. At the Newport Summit, "the adoption of the Readiness Action Plan", which was already adopted at the first session of the North Atlantic Council, was crucial for setting the direction of the Alliance's strategic adaptation to the revised security situation. The plan constituted a fundamental indicator of the Alliance's adaptation direction. That document was covert, but its general provisions were repeated in the overt final declaration of the Summit (paragraphs 5-12). It set out as follows (Koziej and Pietrzak 2014) ${ }^{13}$ :

1. Continued presence of allied troops in the region (breaking the taboo of the wider presence of NATO forces in the states admitted to the Alliance after 1999). The provision shall guarantee the permanent presence of allied troops on the eastern flank regulated by the cyclical rotation. It shall function as a kind of the allied "guard" strategically watching over various states in the region. Logistical and hardware bases shall be established for the needs of the troops staying and exercising in the region;

2. Establishment of the command centres on the eastern flank, along with support and security elements - the battalion-level commands shall be established in several countries of the region (including Poland);

3. Reinforcement of NATO (NATO Response Force) by setting up Very High Readiness Joint Task Forces (VJTF) within its framework. The Final Declaration states the readiness to take action within a few days. Rapid Response Forces are often referred to as "spearheads";

4. Development of permanent defence plans to realize the most demanding tasks (collective defence operations);

5. Intensification of military exercises on the Alliance's eastern flank;

6. Expansion of the allied infrastructure and deployment of equipment bases on NATO's eastern flank (prepositioning) for rapid and efficient operations,

7. Establishment of the Multinational North-East Corpses Command in Szczecin called High Readiness Corpses. The number of personnel shall be increased (doubling its number to about 400 posts). The Corpses' capability of collective defence shall be upgraded. The Corpses Command shall continuously coordinate the exercises of the allied forces in the region and supervise the allied operations on the eastern flank, including the newly established Rapid Response Forces.

Another important document, which was adopted during the second NAC session, was the Wales Declaration on the Transatlantic Bond. The declaration confirmed the allies' readiness to increase defence expenditures to $2 \%$ of GDP,

\footnotetext{
13 Adaptation of NATO to the new security conditions. Presentation by the NSA Head at the NATO Parliamentary Assembly in Warsaw,
} 
including increasing expenditures on technical modernization (20\% of the total defence expenditures), over a ten-year period. Obviously, the soft provision was a compromise towards the group of states not ready to accept the commitment to a mandatory increase in expenditures. In his speech at the summit, President of the Polish Republic announced the intention to increase, as recommended, the Polish defence budget to $2 \%$ of GDP from 2016. Simultaneously, he also pledged to increase technical modernization expenditures-25\% of the total defence expenditures) (Koziej and Pietrzak 2014)".

In 2016, the Summit was held in Warsaw. It was attended by 28 Alliance delegations, 25 delegations of partner states, the representatives of the General Headquarters, the World Bank as well as NATO, EU, UN Strategic Commands. The main decisions made at that summit had been reached earlier during the foreign and defence ministers' meetings during the preparations for the summits. During those meetings, ministers agreed, among other things, that "the strengthening of the allied defence ought to be implemented on the eastern flank by establishing Enhanced Forward Presence, (Efp) (Soloch and Pietrzak 2016; Taylor 2019)", as well as by the deployment of reinforced multinational battalions in Poland, Estonia, Latvia and Lithuania.

At the Warsaw Summit, the state leaders approved of the decisions and supplemented them with firm declarations concerning their practical implementation. The Summit was also dedicated to discussions on how to strengthen the Alliance in three dimensions: political, military and institutional. Overall, as many as 18 countries expressed their intention to delegate their armed forces in order to set up multinational battalion groups. The leaders made firm commitments regarding their own military contributions. Four state leaders, playing a significant role in NATO, pledged to adopt the functions of framework states in the establishment of the groups. The USA declared to undertake that task in Poland, Germany in Lithuania, the UK in Estonia and Canada in Latvia.

Simultaneously, the proposal to set up the division command, to support and synchronize the activities of all four groups, in Poland was put forward. Moreover, the USA confirmed their plans to deploy the Armored Brigade Combat Team in Poland (from 2017) ${ }^{14}$ in order to support the Alliance's operations.

Other important decisions taken at the Warsaw Summit included the signing of a document on coordination of EU and NATO operations to counter hybrid threats and the migration crisis. Recognition of the cyberspace as an area of warfare as well as intensification of cooperation in the fields of cyberspace and missile defence systems were also agreed upon. Support was given to Georgia's aspirations for the NATO membership, Georgian sovereignty and territorial integrity. Moreover, Russia was called on to withdraw its armed forces from South Ossetia and Abkhazia. Further important declarations included the signing of the agreement between NATO and the European Union on joint cooperation in the field of security, ensuring NATO's commitment to provision of conventional and nuclear weapons. Formation of NATO multinational division in Romania, created by transformation of one

14 Ibidem, s.26. 
Romanian division (one of the states that declared its readiness to co-create it was Poland), expansion of the Romanian-Bulgarian brigade.

Another major NATO Summit was held in Brussels on 11-12 July, 2018. During the Summit it was decided to reinforce deterrence and defence capabilities. The allied leaders approved of the decision to establish the logistics command in Germany to ensure the smooth movement of troops in Europe and to recreate the command in Norfolk, the USA. Its main task was to control and coordinate communication routes in the North Atlantic. NATO leaders also approved of the $4 \times 30$ initiative to upscale response speed capabilities. It was assumed that by 2020 NATO Member States would maintain a high level of readiness of 30 mechanized battalions, 30 air squadrons and 30 combat ships ready to operate in no longer than 30 days.

At the summit, 29 NATO states signed the Joint Declaration on Transatlantic Security and Solidarity - the signatories stated "NATO guarantees the security of our territory and people, freedoms and values that we share-including democracy, personal freedom, human rights and the rule of law". 15 "We are committed to improving the balance of sharing costs and responsibilities for the NATO membership"- they stated in the declaration. The document also confirmed that Russia's recent actions contributed to a reduction of stability and security, leading to an increase in unpredictability of the future. The state leaders also expressed their solidarity with the UK in accusing Russia of the "nowiczok" attack in Salisbury. Moreover, NATO members pledged to "prepare, counter and respond to hybrid threats" as well as to participate in the "international fight against terrorism". The Alliance also agreed to launch talks with Macedonia on its accession. The former Yugoslav republic was to become 30th NATO member under a new name: Republic of North Macedonia. $^{16}$

\section{Conclusions}

Summing up the provisions of the consecutive NATO Summits and the declarations in Brussels of 2018, it can be concluded that they were crucial to the strategy pursued by NATO nowadays. The Alliance's new command structure has become more suited for undertaking effective joint defence operations. Definitely, assessing the consecutive provisions, it can be stated that by introducing the standby initiative, NATO has become capable of putting into operation a greater number of troops almost instantaneously. The Alliance's forward-looking presence in Central and Eastern Europe has also been modified, which should translate into a major increase in the Alliance's defence capabilities in the event of potential enemy aggression (Graf 2018).

\footnotetext{
15 The $4 \times 30$ initiative and new HQs. NATO Summit decisions, tvn24.pl, 17 March 2020. https://tvn24. pl/swiat/decyzje-szczytu-nato-inicjatywa-4x30-i-nowe-dowodztwa-ra852958-2581415/. Accessed 20 March 2020.

16 Ibidem.
} 
The most recent NATO Summit in London of December 2019 reaffirmed the Alliance's unity and commitment to Article 5 of the Washington Treaty stating that an attack on one ally would be considered an attack on all. "In difficult times, we are stronger as an Alliance, and our citizens are safer. Our bond and mutual commitment guarantee our freedoms, our values and our security for 70 years to come. We are working to ensure that NATO guarantees these freedoms, values and security for future generations".- The Alliance's declaration proclaims. ${ }^{17}$

The leaders reaffirmed that NATO guarantees security and fundamental human rights as well as the rule of law on the territory of the Member States for the people living there.

"Solidarity, unity and cohesion are the fundamental principles of our Alliance. As we are working together to prevent conflicts and preserve peace, NATO remains the foundation of our collective defence and the basic forum for consultation and security decisions among the allies. We reaffirm the lasting transatlantic relationship between Europe and North America, the observance of the objectives and principles of the United Nations Charter and our solemn commitment as set out in Article 5 of the Washington Treaty that an attack on one Ally will be considered an attack on all of us"- they reaffirmed in the declaration.

Most importantly for Poland and the Baltic states, NATO leaders agreed on the updated defence plans for Poland and the Member States. They also expressed their criticism of Russia's aggressive actions (Gotkowska and Szymański 2017). ${ }^{18}$

Funding Funding was provided by Miniserstwo Obrony Narodowej Grant No. (143/WZA/74/Dz.S).

\section{Declarations}

Conflict of interest On behalf of all authors, the corresponding author states that there is no conflict of interest.

Open Access This article is licensed under a Creative Commons Attribution 4.0 International License, which permits use, sharing, adaptation, distribution and reproduction in any medium or format, as long as you give appropriate credit to the original author(s) and the source, provide a link to the Creative Commons licence, and indicate if changes were made. The images or other third party material in this article are included in the article's Creative Commons licence, unless indicated otherwise in a credit line to the material. If material is not included in the article's Creative Commons licence and your intended use is not permitted by statutory regulation or exceeds the permitted use, you will need to obtain permission directly from the copyright holder. To view a copy of this licence, visit http://creativecommons.org/licen ses/by/4.0/.

\footnotetext{
17 Ibidem.

18 NATO Summit. There is an agreement on defence plans for Poland, https://www.polsatnews.pl/wiado mosc/2019-12-04/szczyt-nato-jest-porozumienie-ws-planow-obronnych-dla-polski. Accessed 09 Dec 2019.
} 


\section{References}

Adamsky, D. 2015. Cross-domain coercion: The Current Russian art of strategy, ProliferationPapers 54, Paryż i Bruksela. https://www.ifri.org/sites/default/files/atoms/files/pp54adamsky.pdf. Accessed 18 March 2018.

Allen, J., Breedlove, P. M., Lindley-French, J., and Zambellas, G. 2017. Future war NATO? From hybrid war to hyper war via cyber war. Supporting paper of the GLOBSECNATO adaptation initiative, defence \& security. https://www.globsec.org/wp-content/uploads/2017/10/GNAI-Future-WarNATO-JLF-et-al.pdf. Accessed 2019.

Banasiak, M. 2019. Threats to the Russian Federation and the Euro-Atlantic security outlook. Difin, Warsaw.

Banasik, M. 2009. Evolution of NATO's expeditionary forces between 1989 and 2001. Bellona Quarterly Journal No 1/2009 (656): 48-52.

Banasik, M. 2016. Security in the aspect of hybrid threats. Quarterly Journal of Defence 3(19). Scientific Papers of the Department of AON Management and Command, Warsaw.

Banasik, M., and Panek, B. 2017. Security of the North Atlantic Alliance and its Russian problem. Entrepreneurship and Management, vol. 18, paper 5, vol. 2. External and internal security in the face of contemporary challenges-selected issues. http://piz.san.edu.pl/docs/e-XVIII-5-2.pdf. Access 23 Feb 2018.

Belkin, P. 2014. NATO: Response to the crisis in Ukraine and security concerns in Central and Eastern Europe, Washington. https://fas.org/sgp/crs/row/R43478.pdf. Accessed 26 Feb 2019.

Boston S., Johnson M., Beauchamp-Mustafaga N., and Crane Y. K. 2018. Assessing the conventional force imbalance in Europe implications for countering Russian local superiority, Santa Monica. https://www.rand.org/content/dam/rand/pubs/research_reports/RR2400/RR2402/RAND_RR2402. pdf. Accessed 26 Feb 2019.

Hodges, B., Doran, P. B., and Bugajski, J. 2019. Strengthening NATO's Eastern Flank: A strategy for Baltic-Black sea coherence. Center for European Policy Analysis, 34. Accessed 03 April 2020.

Mierzwa, D., Mierzwa Dominika, and Sienicki, J. 2020. The new strategic concept of defence expenditures in the NATO member states and the Russian federation - The comparative analysis international business information management association (IBIMA), Conference (IBIMA) 1-2 April 2020 Seville, Spain. In Education excellence and innovation management: A 2025 vision to sustain economic development during global challenges, ed. Khalid S. Soliman.

Wierzbicki, S. 2015. Cyber wars as part of an unconventional interstate confrontation. Pragmatic reality, inevitable future, University of Natural Sciences and Humanities in Siedlce, Institute of Social Sciences and Security, no 2(1).

Wierzbicki, S. 2015. Cyber wars as part of unconventional interstate confrontation. Pragmatic reality, inevitable future, University of Natural Sciences and Humanities in Siedlce, Institute of Social Sciences, No 2(1). Accessed 03 April 2020.

\section{Internet sources}

Adamsky, D. 2015. Cross-domain coercion: The current Russian art of strategy. ProliferationPapers 54, Paryż i Bruksela. https://www.ifri.org/sites/default/files/atoms/files/pp54adamsky.pdf. Accessed 03 April 2020.

Allen, J., Breedlove, P. M., Lindley-French, J., Zambellas, G. 2017. Future war NATO? From hybrid war to hyper war via cyber war. Supporting paper of the globsecnato adaptation initiative, defence \& security. https://www.globsec.org/wp-content/uploads/2017/10/gnai-future-war-nato-jlf-et-al.pdf. Accessed 2019.

Allen, J., Breedlove, P. M., Lindley-French, J., and Zambellas, G. 2017. Future war NATO? From hybrid war to hyper war via cyber war. Supporting paper of the globsecnato adaptation initiative, defence \& security. https://www.globsec.org/wp-content/uploads/2017/10/gnai-future-war-nato-jlf-et-al.pdf. Accessed 03 April 2020.

Bartles, C. K. 2016. Getting Gerasimov right. Military Review. https://community.apan.org/cfs-file/_ key/docpreview-s/00-00-00-11-18/20151229-Bartles-_2D00_-Getting-Gerasimov-Right.pdf. Accessed 18 Feb 2018. 
Belkin, P. 2014. NATO: Response to the crisis in Ukraine and Security Concerns in Central and Eastern Europe, Waszyngton. https://fas.org/sgp/crs/row/R43478.pdf. Accessed 03 April 2020.

Boston, S., Johnson, M., Beauchamp-Mustafaga, N., and Crane Y. K. 2018. Assessing the conventional force imbalance in Europe implications for countering Russian local superiority, Santa Monica. https://www.rand.org/content/dam/rand/pubs/research_reports/RR2400/RR2402/RAND_RR2402. pdf. Accessed 03 April 2020.

Cranny-Evans, S. 2019. Russia's Palantin electronic warfare system makes training debut, janes.com. https://www.janes.com/article/91413/russia-s-palantin-electronic-warfare-system-makes-trainingdebut/. Accessed 01 Feb 2020.

Estonian Foreign Intelligence Service. 2020. International security and Estonia 2020. https://www.valis luureamet.ee/pdf/raport-2020-en.pdf. str.6-7. Accessed 10 Jan 2020.

Gawęda, M. 2015 Russian response to AWACS and drones. The system of elektronic war of Krasuch, defence24.pl, 11 Feb 2015. https:/www.defence24.pl/rosyjska-odpowiedz-na-awacs-i-drony-system-walki-elektronicznej-krasucha/. Accessed 10 Feb 2020.

Gawęda, M. 2018. Russian bastions A2/AD [ANALIZA], defence24.pl, 29 July 2018. https://www.defen ce24.pl/rosyjskie-bastiony-a2ad-analiza/. Accessed 20 Feb 2020.

Gorenburg, D. 2017. Russia's military modernization plans: 2018-2027, PONARS Eurasia is an international network of scholars advancing new approaches to research on security, politics, economics, and society in Russia and Eurasia. http://www.ponarseura-sia.org/memo/russias-military-moder nization-plans-2018-2027. Accessed 18 March 2018.

Gotkowska, J., and Szymański, P. 2017. Russia and security in the Baltic Sea region. Some recommendations for policy-makers, Baltic Sea Region Policy Briefing series 1/2017, Warsaw. http://www.centr umbalticum.org/files/2157/BSR_Poli_Briefing_1_201pdf. Accessed 18 March 2018

Graf, J. 2018. Szatkowski, The provisions of the NATO Summit in Brussels crucial to the reinforcement strategy [interview], defence24.pl. 17 July 2018. https://www.defence24.pl/szatkowski-dla-defen ce24pl-postanowienia-szczytu-nato-w-brukseli-kluczowe-dla-strategii-wzmocnienia/. Accessed 09 Dec 2019.

Grygiel, J., and Wess Mitchell, A. 2014. The best defense: A preclusive strategy to defend the NATO Frontier, Portal internetowy American Interest. https://www.the-american-interest.com/2014/12/ 02/a-preclusive-strategy-to-defend-the-nato-frontier/. Accessed 28 March 2019.

Koziej, S., and Pietrzak, P. 2014. NATO Summit in Wales: conditions, results, conclusions for Poland, pp. 21-23. bbn.gov.pl. https://www.bbn.gov.pl/ftp/dok/11-29\%20koziej\%20pietrzak.pdf/. Accessed 01 March 2020.

Koziej, S. 2014. Adaptation of NATO to the new security conditions. Presentation by the Head of the NSA at the NATO Parliamentary Assembly in Warsaw, bbn.gov.pl. https://www.bbn.gov.pl/pl/ wydarzenia/6020, quotAdaptacja-NATO-do-nowych-warunkow-bezpieczenstwaquot-wystapienieszefa-BBN.html/. Accessed 25 Feb 2020.

Фененко, А. В. 2016. Концепция быстрого глобального удара в контексте развитиявоенной стратегии США, Вестн. No 4. http://fmp.msu.ru/attachments/article/421/FENENKO_2016_4.pdf. Accessed 16 Jan 2019.

Soloch, P., and Pietrzak, P. 2016. NATO Summit in Warsaw: conditions, results, conclusions for Poland, bbn.gov.pl. https://www.bbn.gov.pl/ftp/dok/03/37-40_KBN_Soloch_Pietrzak.pdf/ s. 23. Accessed 01 March 2020.

Taylor, P. 2019. "Fort Trump" or Nothing? Poland and the future of the European Security, Friends of Europe Styczeń. https://www.friendsofeurope.org/sites/default/files/media-files/2018_foe_sec_pub_ poland_web_polish.pdf. Accessed 03 April 2020.

Publisher's Note Springer Nature remains neutral with regard to jurisdictional claims in published maps and institutional affiliations. 